\title{
Complete rectal prolapse in the elderly: systematic review of surgical treatment
}

\author{
C Rispoli", N Rocco, L lannone, M Persico, B Amato \\ From de Senectute: Age and Health Forum \\ Catanzaro, Italy. 5-7 December 2009
}

\section{Background}

Complete rectal prolapse is a disease characterized by the complete protrusion of rectal wall through the anus. This disability affects mostly elderly women ( $>65$ years). Several surgical techniques have been described for the treatment of this condition with both perineal and abdominal approach. Under trial condition none of them have been demonstrated to be the best choice in terms of recurrence, postoperative faecal incontinence or stipsis and cost-effectiveness.

The aim of our study was to compare different surgical techniques for complete rectal prolapse in the elderly.

\section{Materials and methods}

All potentially relevant studies have been searched on electronic databases such as PUBMED, CENTRAL and EMBASE. Only randomized controlled trials have been included in the review.

Our comparisons have been: surgical treament versus no treatment or non-surgical treatment, abdominal versus perineal approach, one abdominal method versus another and one perineal method versus another.

Main outcomes were: complete recurrence, residual mucosal prolapse, faecal incontinence and constipation.

\section{Results}

Ten RCTs were included in this review with a total of 336 patients. Data about patients older than 65 years have been extracted from 6 trials. Included trials compared different surgical techniques with both laparoscopic, laparotomic and perineal approach. Studies analysis showed high heterogeneity about objectives, surgical techniques and considered outcomes. No difference has been found about surgical approach (abdominal or perineal) and methods of fixing the rectum during abdominal surgery. Resection

\footnotetext{
Dipartimento Assistenziale di Chirurgia Generale, Geriatrica ed Endoscopia
} Diagnostica ed Operativa, Università Federico II di Napoli, Italy rectopexy showed a lower postoperative constipation rate compared to rectopexy alone.

\section{Conclusions}

The small sample size, the low methodological quality and the heterogeneity of the surgical procedures weaken the clinical usefulness of this review. There is no clear difference between the methods of surgical approach being the confidence of the surgeon in performing one procedure rather than another in the main outcome determinant. Larger and higher-quality trials are needed to improve the evidence to define the best surgical treatment for rectal prolapse.

Published: 19 May 2010

\section{References}

1. Eu KW, Seow-Choen F: Functional problems in adult rectal prolapse and controversies in surgical treatment. British Journal of Surgery 1997, 84(7):904-11.

2. Solomon MJ, Young CJ, Eyers AA: Randomized clinical trial of laparoscopic versus open abdominal rectopexy for rectal prolapse. British Journal of Surgery 2002, 89(1):35-9.

\section{doi:10.1186/1471-2318-10-S1-A30}

Cite this article as: Rispoli et al:: Complete rectal prolapse in the elderly: systematic review of surgical treatment. BMC Geriatrics 2010 10(Suppl 1): A30.

Submit your next manuscript to BioMed Central and take full advantage of:

- Convenient online submission

- Thorough peer review

- No space constraints or color figure charges

- Immediate publication on acceptance

- Inclusion in PubMed, CAS, Scopus and Google Scholar

- Research which is freely available for redistribution

Submit your manuscript at www.biomedcentral.com/submit
C Biomed Central 